\title{
Foliar Silicon and Titanium Applications Influence Growth and Quality Characteristics of Annual Bedding Plants
}

\author{
Brittnay Whitted-Haag ${ }^{1}$, David E. Kopsel1 ${ }^{1, *}$, Dean A. Kopsel1 ${ }^{2}$ and Robert L. Rhykerd ${ }^{1}$ \\ ${ }^{I}$ Department of Agriculture, Illinois State University, 125 Ropp Agriculture Building, Normal, IL 61790, USA; \\ ${ }^{2}$ Plant Sciences Department, The University of Tennessee, 2431 Joe Johnson Drive, Knoxville, TN 37996, USA
}

\begin{abstract}
This study investigated the effects of foliar Si and Ti applications on annual bedding plant growth and quality in soilless media. The five annual plant species selected were geranium (Pelargonium $x$ hortorum 'Elite Cherry'), impatiens (Impatiens walleriana 'Accent White'), pansy (Viola $x$ wittrockiana 'Delta Premium Marina'), petunia (Petunia $x$ hybrid 'Celebrity White') and snapdragon (Antirrhinum majus 'Montego Purple'). Sodium silicate $\left(\mathrm{NaSiO}_{3}\right)$ supplied foliar treatments of $0,50,100,150$ and $200 \mathrm{mg} \mathrm{Si} \cdot \mathrm{L}^{-1}$ and Ti-ascorbate (Tytanit ${ }^{\mathbb{B}}$ ) supplied foliar treatments of $0,25,50,75$ and $100 \mathrm{mg} \mathrm{Ti} \cdot \mathrm{L}^{-1}$. Silicon treatments affected plant height for all five species, while Ti treatments only affected plant height for geranium, petunia and snapdragon. Snapdragon plant height increased linearly in response to Si and Ti treatments. Plant height increased, then decreased quadratically for geranium with Ti treatments and pansy with Si treatments. The number of days to flower for petunias exhibited a linear decrease with Ti treatments while impatiens exhibited a linear increase with Si and Ti treatments. Geranium responded with a quadratic decrease, then increase for the number of days to flower with increasing Ti treatments. The chlorophyll SPAD content of impatiens exhibited a linear decrease in response to Ti treatments, while geranium had the same response to Si treatments. Silicon and Ti supplementations were found to affect growth and quality characteristics of annual bedding plants. However, this response was species specific and further research is needed to assess the specific impacts of $\mathrm{Si}$ and $\mathrm{Ti}$ on additional annual crop species and varieties grown in soilless media.
\end{abstract}

Keywords: Chlorophyll, days to flower, flower diameter, foliar supplementation, micronutrient, number of leaves, plant height, stem diameter, SPAD, soilless media.

\section{INTRODUCTION}

According to the 2010 USDA floriculture crop summary, the wholesale value of floriculture crops grown in the U.S. was estimated to be $\$ 4.13$ billion; up 3\% from 2009 . Bedding plants made up the largest sector of floriculture crops and were valued at $\$ 1.91$ billion; up 4\% from 2009 [1]. The term bedding plant refers to any herbaceous plant produced and sold for planting in the landscape, garden or large containers [2]. In order for growers to ensure bedding plants possess desired characteristics, proper growing techniques, scheduling and fertilization are required.

The current industry practice for annual bedding plants is the use of soilless growing media [3]. Soilless media is frequently used in the greenhouse industry because of its light weight, good water holding capacity, and uniform consistency [4]. However, soilless media contains little or no elemental nutrients that are found naturally in soil, so added fertilization is necessary. Aside from the essential elements for plant growth, researchers have identified several beneficial elements, including silicon (Si) and titanium (Ti), which can promote or improve the growth and development of some plant species or under specific growth conditions [5].

*Address correspondence to this author at the Department of Agriculture, Illinois State University, 125 Ropp Agriculture Building, Campus Box 5020, Normal, IL 61790-5020, USA; Tel: (309) 438-3275;

Fax: (309) 438-5653; E-mail: dkopsell@ilstu.edu
Silicon is the second most abundant element on the Earth's surface and has been researched in the agriculture and horticulture industry since $1840[6,7]$. Silicon exists as monosilicic acid $\left[\mathrm{Si}(\mathrm{OH})_{4}\right]$ in soils at concentrations between $30-40 \mathrm{mg} \mathrm{SiO}_{2} \cdot \mathrm{L}^{-1}$. Silicon soil concentrations are roughly double that of phosphorus $[6,8]$. It is absorbed by plants in the form of silicic acid in the same magnitude as other micronutrients [6]. Silicon is also the only beneficial element that does not cause toxicity or serious injury to plants under excessive amounts [6]. Previous research with supplemental Si has shown positive effects, including inhibiting biotic and abiotic stresses as well as overall plant growth on some horticultural plants [9-11]. However, Si supplementation has not been extensively studied with a broad range of horticultural crops and it is unknown how Si may affect individual plant species.

Titanium is also classified as a beneficial element for plant growth [5]. It is the tenth most abundant element found on the Earth's surface, existing at concentrations of approximately $4,400 \mathrm{mg} \cdot \mathrm{kg}^{-1}$ in soils $[7,12]$. It is most commonly found as an oxide in igneous rocks [7]. Most plants contain about $1 \mu \mathrm{g} \cdot \mathrm{g}^{-1}$ of $\mathrm{Ti}$, while fruit and vegetable plants contain about $2 \mu \mathrm{g} \cdot \mathrm{g}^{-1}$ [7]. Common methods of Ti application include foliar applications or as a nutrient solution additive [13]. Titanium supplementation through Ti-ascorbate can encourage carbohydrate production and growth of plants as well as increase yields of certain fruits and vegetables [12]. 
Research on supplemental applications of $\mathrm{Si}$ and $\mathrm{Ti}$ to plants has demonstrated beneficiary results depending on plant species, plant age, and tissue concentration of other minerals [5]. Because of the promising results of previous research using both $\mathrm{Si}$ and $\mathrm{Ti}$, these two elements may have the potential to impact the growth of annual bedding plants grown in soilless media when applied during production. Therefore, the objectives of this research were to: 1) determine if $\mathrm{Si}$ and Ti supplementation through foliar applications will impact horticultural traits of greenhouse-grown annual bedding plants in soilless media; and 2) determine the concentrations of supplemental foliar applications of $\mathrm{Si}$ and $\mathrm{Ti}$ which amplify horticultural traits the most.

\section{MATERIALS AND METHODS}

\section{Plant Culture}

Two greenhouse crop experiments were conducted simultaneously from 26 January 2010 to 15 May 2010. The five annual plant species and cultivars selected for each experiment were geranium (Pelargonium $x$ hortorum 'Elite Cherry'), impatiens (Impatiens walleriana 'Accent White'), pansy (Viola $x$ wittrockiana 'Delta Premium Marina'), petunia (Petunia $x$ hybrid 'Celebrity White') and snapdragon (Antirrhinum majus 'Montego Purple'). Seeds (Harris Seeds, Rochester, MN) were sown into germination trays $(53.96 \mathrm{~cm}$ x $27.46 \mathrm{~cm} \times 3.28 \mathrm{~cm}$; T.O. Plastics, Clearwater, $\mathrm{MN}$ ) with a soilless commercial media, Mix No. 3-B (Conrad Fafard, Inc., Agawam, MA). Plants were grown in a glass-covered greenhouse (lat. $40^{\circ} 30^{\prime} \mathrm{N}$ ) with night/day temperatures of $14^{\circ} \mathrm{C} / 22^{\circ} \mathrm{C}$ under natural photoperiod and an average relative humidity of $80 \%$. Seedlings were transplanted into 6-pack containers (606 Com-Packs Bedding Plant Containers; T.O. Plastics) containing a soilless commercial media, Mix No. 3B (Conrad Fafard, Inc., Agawam, MA) when four to six true leaves were present. Geranium seedlings were transplanted to round pots $(0.98 \mathrm{~L}$; ITML, Middlefield, $\mathrm{OH})$ containing soilless commercial media Mix No. 3-B to be finished. Plants were fertilized weekly using a 20N-10P-20K complete fertilizer with micronutrients (Peter's Professional, The Scotts Co., Marysville, $\mathrm{OH}$ ). After three weeks and adequate root development, plants were arranged on benches in a randomized block design by species and treatment group and foliar nutrient treatments were initiated.

\section{Experiment 1: Silicon (Si) Supplementation}

In this experiment $\mathrm{Si}$ was applied as sodium meta-silicate pentahydrate $\left(\mathrm{Na}_{2} \mathrm{SiO}_{3} \cdot 5 \mathrm{H}_{2} \mathrm{O}\right.$, Fisher Scientific, Waltham, MA) dissolved in deionized water at four different concentrations each with six replicates (six plants per replicate) per treatment. Silicon concentrations were $0,50,100,150$ and $200 \mathrm{mg} \mathrm{Si} \cdot \mathrm{L}^{-1}$. A nonionic surfactant $\left(\mathrm{DRI}^{\circledR}, \mathrm{KALO}\right.$, Overland Park, KS) at $0.125 \%$ was added to the stock solutions to ensure adequate spray coverage. No precipitate was visible in stock solutions. Treatments were applied using a 32 oz. heavy-duty spray bottle (Menards, Eau Claire, WI) and plants received uniform applications of $3.3 \mathrm{ml}$ of solution per spray until run off occurred. The replicates received four weekly foliar applications, except for geranium, which received seven weekly applications. The concentrations of the nutrient sources were determined from previous research $[9,14]$.

\section{Experiment 2: Titanium (Ti) Supplementation}

In this experiment the Ti source, Ti-ascorbate $\left(\mathrm{Tytanit}^{\circledR}\right.$, Intermag, Olkusz, Poland) dissolved in deionized water, was applied at four different concentrations each with six replicates (six plants per replicate) per treatment. Titanium concentrations were $0,25,50,75$ and $100 \mathrm{mg} \mathrm{Ti} \cdot \mathrm{L}^{-1}$. A nonionic surfactant $\left(\mathrm{DRI}^{\circledR}, \mathrm{KALO}^{\mathrm{B}}\right.$ Overland Park, KS) at $0.125 \%$ was added to the solutions to ensure adequate spray coverage. No precipitate was visible in stock solutions. Treatments were applied using a $32 \mathrm{oz}$. heavy-duty spray bottle and plants received $3.3 \mathrm{ml}$ of solution per spray. The replicates received four weekly foliar applications, except for geranium, which received seven weekly applications.

\section{Data Collection and Statistical Analyses}

Data collected weekly included plant height, stem diameter ('Accent White' impatiens and 'Montego Purple' snapdragon only), number of leaves, chlorophyll content, days to flower and diameter of flower ('Accent White' impatiens, 'Celebrity White' petunia and 'Delta Premium Marina' pansy only). The stem diameter was measured at the base of the stem using a digital caliper. The chlorophyll content of each replicate was estimated using a SPAD meter (Konica Minolta Sensing, Inc., Osaka, Japan). Data collection was concluded when each species reached a marketable size as indicated by industry scheduling standards [3]. The data was analyzed using the GLM procedure of SAS statistical analysis software (Version 9.1, SAS Institute, Cary, NC). Analysis of variance and regression analysis were performed to determine the relationship between dependent variables and $\mathrm{Si}$ and Ti treatments.

\section{RESULTS AND DISCUSSION}

\section{Experiment 1: Silicon (Si) Supplementation}

\section{Plant Height}

Silicon supplementation had a significant effect on the plant height of 'Elite Cherry' geranium $(P<0.0001)$, 'Accent White' impatiens $(P=0.006)$, 'Celebrity White' petunia $(P<0.0001)$, 'Delta Premium Marina' pansy $(P<0.0001)$, and 'Montego Purple' snapdragon $(P=0.041)$. The plant heights of the control treatments of all species were within reported ranges (Tables 1-5) [3]. Significant linear decreases in plant height were recorded in 'Elite Cherry' geranium $(P=0.0058)$, 'Accent White' impatiens $(P=0.0398)$ and 'Celebrity White' petunia $(P=0.04)$ in response to increasing foliar Si treatment. Plant height increased, and then decreased quadratically $(P=0.0016)$ in 'Delta Premium Marina' pansy in response to increasing foliar Si treatment. Kamenidou et al. [9, 14] reported that $\mathrm{Si}$ supplementation by substrate drench of $\mathrm{KSiO}_{3}\left(200 \mathrm{~g} \cdot \mathrm{m}^{-3}\right)$ decreased plant height in both ornamental sunflower (Helianthus annuus) and zinnia (Zinnia elegans). In contrast, our study found 'Montego Purple' snapdragon had a significant linear increase $(P=0.0273)$ in plant height as the Si treatments increased from $50 \mathrm{mg} \cdot \mathrm{L}^{-1} \mathrm{Si}$ to $200 \mathrm{mg} \cdot \mathrm{L}^{-1} \mathrm{Si}$ (Table 5). Kamenidou et al. [9], while researching different $\mathrm{Si}$ treatments and application forms, 
Table 1. Mean values ${ }^{\mathrm{a}}$ of 'Elite Cherry' geranium growth parameters after plants reached marketable size under greenhouse conditions at Illinois State University, Normal, IL with silicon treatments (Si LEVEL) varying from $0 \mathrm{mg} \mathrm{Si}^{-1}$ to $200 \mathrm{mg}$ $\mathrm{Si} \cdot \mathbf{L}^{-1}$.

\begin{tabular}{|c|c|c|c|c|}
\hline $\begin{array}{c}\text { Si LEVEL } \\
\left(\mathrm{mg} \cdot \mathbf{L}^{-1}\right)\end{array}$ & $\begin{array}{c}\text { Plant Height } \\
\text { (cm) }\end{array}$ & $\begin{array}{l}\text { Days to Flower } \\
\text { (anthesis) }\end{array}$ & $\begin{array}{l}\text { SPAD Chlorophyll } \\
\left(\mathrm{mg} \cdot \mathrm{m}^{-2}\right)\end{array}$ & Number of Leaves \\
\hline 0 & $7.6 \pm 1.09$ & $105.17 \pm 0.70$ & $51.9 \pm 1.36$ & $16.31 \pm 1.82$ \\
\hline 50 & $8.6 \pm 1.30$ & $102.17 \pm 0.70$ & $51.8 \pm 1.03$ & $17.60 \pm 2.55$ \\
\hline 100 & $6.8 \pm 1.04$ & $105.33 \pm 1.12$ & $52.5 \pm 0.98$ & $16.78 \pm 2.79$ \\
\hline 200 & $6.7 \pm 1.36$ & $105.17 \pm 1.08$ & $52.1 \pm 1.31$ & $17.14 \pm 2.52$ \\
\hline \multicolumn{5}{|l|}{ Contrast $^{\mathrm{d}}$} \\
\hline $\mathrm{L}$ & $* *$ & NS & $*$ & NS \\
\hline $\mathrm{Q}$ & $*$ & $* * *$ & $*$ & NS \\
\hline
\end{tabular}

${ }^{\text {a }}$ Mean of 6 replications, 6 plants each \pm standard deviation.

${ }^{\mathrm{b}}$ Plant height was measured from base of the crown to tip of the apical bud in centimeters $(\mathrm{cm})$.

${ }^{\mathrm{c}}$ Mean chlorophyll content of mature leaves measured using a hand-held SPAD meter.

${ }^{\mathrm{d}}$ Significance for linear (L) and quadratic (Q) orthogonal contrasts for Si level.

NS, ${ }^{*}{ }^{* *},{ }^{* * *}$ Non-significant or significant at $P \leq 0.10, P \leq 0.01, P \leq 0.001$, respectively.

Table 2. Mean values ${ }^{\mathrm{a}}$ of 'Accent White' impatiens growth parameters after plants reached marketable size under greenhouse conditions at Illinois State University, Normal, IL with silicon treatments (Si LEVEL) varying from $0 \mathrm{mg} \mathrm{Si} \cdot \mathrm{L}^{-1}$ to $200 \mathrm{mg}$ $\mathrm{Si} \cdot \mathbf{L}^{-1}$.

\begin{tabular}{|c|c|c|c|c|c|c|}
\hline $\begin{array}{c}\text { Si LEVEL } \\
\left(\mathrm{mg} \cdot \mathrm{L}^{-1}\right)\end{array}$ & $\begin{array}{c}\text { Plant Height }^{\mathrm{b}} \\
(\mathrm{cm})\end{array}$ & $\begin{array}{c}\text { Days to Flower } \\
\text { (anthesis) }\end{array}$ & $\begin{array}{c}\text { SPAD } \\
\text { Chlorophyll }^{\mathbf{c}} \\
\left(\mathbf{m g} \cdot \mathbf{m}^{-2}\right)\end{array}$ & $\begin{array}{c}\text { Number of } \\
\text { Leaves }\end{array}$ & $\begin{array}{c}\text { Stem Diameter } \\
(\mathrm{mm})\end{array}$ & $\begin{array}{l}\text { Flower Diameter } \\
(\mathbf{c m})\end{array}$ \\
\hline 0 & $8.1 \pm 1.32$ & $81.19 \pm 0.82$ & $36.8 \pm 2.20$ & $31.30 \pm 1.26$ & $8.9 \pm 0.38$ & $3.9 \pm 0.28$ \\
\hline 50 & $8.9 \pm 0.87$ & $83.36 \pm 2.29$ & $35.6 \pm 1.24$ & $28.27 \pm 1.61$ & $8.2 \pm 0.48$ & $4.2 \pm 0.19$ \\
\hline 100 & $6.8 \pm 0.70$ & $81.53 \pm 0.84$ & $31.9 \pm 1.55$ & $29.00 \pm 2.67$ & $7.6 \pm 0.64$ & $4.2 \pm 0.14$ \\
\hline 150 & $7.6 \pm 0.96$ & $85.09 \pm 2.16$ & $37.5 \pm 2.87$ & $27.78 \pm 1.40$ & $7.9 \pm 0.67$ & $4.0 \pm 0.26$ \\
\hline 200 & $7.3 \pm 0.42$ & $83.99 \pm 1.14$ & $38.3 \pm 4.02$ & $29.97 \pm 0.66$ & $7.9 \pm 0.29$ & $3.8 \pm 0.14$ \\
\hline \multicolumn{7}{|l|}{ Contrast $^{\mathrm{d}}$} \\
\hline $\mathrm{L}$ & $*$ & $* *$ & NS & NS & $* *$ & NS \\
\hline Q & NS & $*$ & $*$ & $* *$ & $* * *$ & $* *$ \\
\hline
\end{tabular}

${ }^{a}$ Mean of 6 replications, 6 plants each \pm standard deviation.

${ }^{\mathrm{b}}$ Plant height was measured from base of the crown to tip of the apical bud in centimeters $(\mathrm{cm})$.

${ }^{\mathrm{c}}$ Mean chlorophyll content of mature leaves measured using a hand-held SPAD meter.

${ }^{\mathrm{d}}$ Significance for linear (L) and quadratic (Q) orthogonal contrasts for Si level.

NS, ${ }^{* * *}{ }^{* * *}$ Nonsignificant or significant at $P \leq 0.10, P \leq 0.01, P \leq 0.001$, respectively.

found plant height in ornamental sunflowers to increase when hydrous potassium silicate $\left(\mathrm{KSiO}_{3}\right)$ powder $\left(140 \mathrm{~g} \cdot \mathrm{m}^{-3}\right)$ was incorporated into the soil. Our results, and the reported literature, indicate that annual bedding plant height response to Si treatment and application form is species specific.

\section{Stem Diameter}

The stem diameter of 'Accent White' impatiens $(P=0.0015)$ and 'Montego Purple' snapdragon $(P<0.0001)$ was significantly affected by $\mathrm{Si}$ supplementation. The orthogonal contrasts were the same for both species, exhibiting a linear decrease $(P=0.0019$ and, $P<0.0001$, respectively).
The stem diameter for 'Accent White' impatiens decreased from $8.95 \mathrm{~mm}$ for the control group to $7.89 \mathrm{~mm}$ for the 200 $\mathrm{mg} \cdot \mathrm{L}^{-1} \mathrm{Si}$ concentration treatment group (Table 2). 'Montego Purple' snapdragon stem diameter decreased slightly less than $1 \mathrm{~mm}$ from the control to the highest Si concentration treatment (Table 5). Previous research found $\mathrm{KSiO}_{3}$ substrate drenches $\left(200 \mathrm{mg} \cdot \mathrm{L}^{-1}\right)$ and media incorporation of $\mathrm{KSiO}_{3}$ $\left(280 \mathrm{~g} \cdot \mathrm{m}^{-3}\right)$ and rice husk ash $\left(100 \mathrm{~g} \cdot \mathrm{m}^{-3}\right)$ to increase stem diameter in zinnia [14]. However, foliar applications of sodium silicate did not affect the stem diameter in zinnia [14]. The same researchers also found several combinations of $\mathrm{Si}$ sources and concentrations to increase the stem diameter in 
Table 3. Mean values a of 'Celebrity White' petunia growth parameters after plants reached marketable size under greenhouse

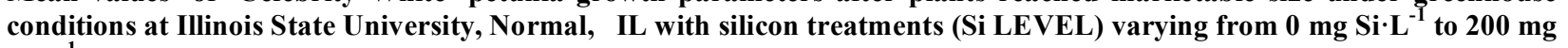
$\mathrm{Si} \cdot \mathbf{L}^{-1}$.

\begin{tabular}{|c|c|c|c|c|c|}
\hline $\begin{array}{l}\text { Si LEVEL } \\
\left(\mathrm{mg} \cdot \mathbf{L}^{-1}\right)\end{array}$ & $\begin{array}{l}\text { Plant Height }^{\mathrm{b}} \\
\text { (cm) }\end{array}$ & $\begin{array}{l}\text { Days to Flower } \\
\quad \text { (anthesis) }\end{array}$ & $\begin{array}{c}\text { SPAD } \\
\text { Chlorophyll }^{\mathrm{c}} \\
\left(\mathrm{mg} \cdot \mathrm{m}^{-2}\right)\end{array}$ & Number of Leaves & $\begin{array}{c}\text { Flower Diameter } \\
(\mathbf{m m})\end{array}$ \\
\hline 50 & $10.9 \pm 1.26$ & $78.35 \pm 1.28$ & $36.9 \pm 1.53$ & $27.21 \pm 4.10$ & $6.1 \pm 0.31$ \\
\hline 100 & $07.2 \pm 0.50$ & $78.67 \pm 2.02$ & $34.7 \pm 2.11$ & $26.55 \pm 1.52$ & $5.9 \pm 0.26$ \\
\hline 200 & $10.5 \pm 0.93$ & $78.26 \pm 1.39$ & $36.7 \pm 3.17$ & $28.56 \pm 2.25$ & $6.1 \pm 0.53$ \\
\hline \multicolumn{6}{|l|}{ Contrast $^{\mathrm{d}}$} \\
\hline $\mathrm{L}$ & $*$ & NS & NS & NS & NS \\
\hline
\end{tabular}

${ }^{a}$ Mean of 6 replications, 6 plants each \pm standard deviation.

${ }^{\mathrm{b}}$ Plant height was measured from base of the crown to tip of the apical bud in centimeters $(\mathrm{cm})$

${ }^{\mathrm{c}}$ Mean chlorophyll content of mature leaves measured using a hand-held SPAD meter.

${ }^{\mathrm{d}}$ Significance for linear (L) and quadratic (Q) orthogonal contrasts for Si level.

NS, ${ }^{* * * *}$ Nonsignificant or significant at $P \leq 0.10, P \leq 0.001$, respectively.

Table 4. Mean values ${ }^{a}$ of 'Delta Premium Marina' pansy growth parameters after plants reached marketable size under green-

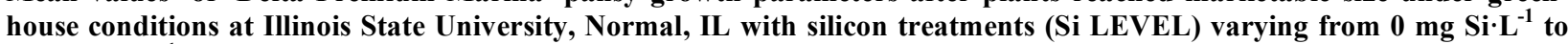
$200 \mathrm{mg} \mathrm{Si} \cdot \mathbf{L}^{-1}$.

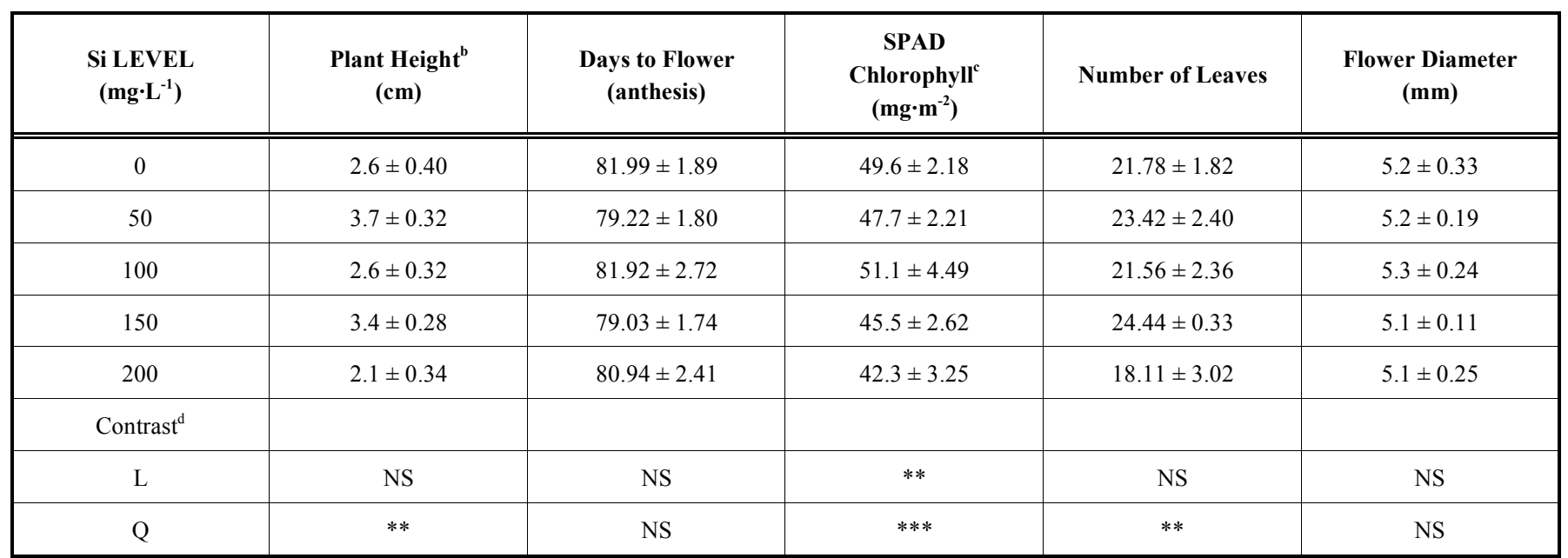

${ }^{a}$ Mean of 6 replications, 6 plants each \pm standard deviation.

${ }^{\mathrm{b}}$ Plant height was measured from base of the crown to tip of the apical bud in centimeters $(\mathrm{cm})$

${ }^{\mathrm{c}}$ Mean chlorophyll content of mature leaves measured using a hand-held SPAD meter.

${ }^{\mathrm{d}}$ Significance for linear (L) and quadratic (Q) orthogonal contrasts for Si level.

$\mathrm{NS},{ }^{* *},{ }^{* * *}$ Nonsignificant or significant at $P \leq 0.01, P \leq 0.001$, respectively.

ornamental sunflower [9, 15]. Foliar applications of sodium silicate $\left(\mathrm{NaSiO}_{3}\right)$ on the stem diameter of sunflowers were significant with 50,100 and $150 \mathrm{mg} \cdot \mathrm{L}^{-1} \mathrm{Si}$ treatments [9]. Our results, and the reported literature, indicate that plant height response to $\mathrm{Si}$ treatment and application form is species specific.

\section{Number of Leaves}

Several species of annual bedding plants reacted significantly to Si supplementation for the number of leaves produced per plant. Plant species influenced by Si treatments were 'Accent White' impatiens $(P=0.0085)$, 'Delta Premium Marina' pansy $(P=0.0005)$, and 'Montego Purple' snapdragon $(P<0.0001)$. However, Si treatments had no significant effect on number of leaves in 'Elite Cherry' geranium $(P=0.1889)$ and 'Celebrity White' petunia $(P=0.3957)$. The number of leaves on 'Accent White' impatiens exhibited a quadratic decrease, then increase $(P=0.0055)$ as $\mathrm{Si}$ treatments increased. Higher Si concentrations than what were used in this study may prove to be beneficial for the number of leaves in impatiens. The effect was the opposite for 'Delta Premium Marina' pansy whose number of leaves 
Table 5. Mean values ${ }^{\mathrm{a}}$ of 'Montego Purple' snapdragon growth parameters after plants reached marketable size under greenhouse conditions at Illinois State University, Normal, IL with silicon treatments (Si LEVEL) varying from $0 \mathrm{mg} \mathrm{Si}^{-1} \mathbf{L}^{-1}$ to $200 \mathrm{mg}$ $\mathrm{Si} \cdot \mathbf{L}^{-1}$.

\begin{tabular}{|c|c|c|c|c|c|}
\hline $\begin{array}{c}\text { Si LEVEL } \\
\left(\mathrm{mg} \cdot \mathbf{L}^{-1}\right)\end{array}$ & $\begin{array}{c}\text { Plant Height }^{\mathrm{b}} \\
\text { (cm) }\end{array}$ & $\begin{array}{l}\text { Days to Flower } \\
\text { (anthesis) }\end{array}$ & $\begin{array}{c}\text { SPAD } \\
\text { Chlorophyll } \\
\left(\mathbf{m g} \cdot \mathbf{m}^{-2}\right)\end{array}$ & Number of Leaves & Stem Diameter $(\mathrm{mm})$ \\
\hline 50 & $12.2 \pm 0.18$ & $60.50 \pm 0.0$ & $46.9 \pm 4.78$ & $68.42 \pm 1.34$ & $2.5 \pm 0.18$ \\
\hline 100 & $12.5 \pm 1.11$ & $60.50 \pm 0.0$ & $45.5 \pm 3.62$ & $67.19 \pm 2.25$ & $2.5 \pm 0.10$ \\
\hline 200 & $12.3 \pm 0.46$ & $60.50 \pm 0.0$ & $46.1 \pm 1.89$ & $72.06 \pm 1.12$ & $2.0 \pm 0.16$ \\
\hline \multicolumn{6}{|l|}{ Contrast $^{\mathrm{d}}$} \\
\hline $\mathrm{L}$ & * & NS & NS & $* * *$ & $* * *$ \\
\hline Q & $* *$ & NS & NS & $* * *$ & $* * *$ \\
\hline
\end{tabular}

${ }^{a}$ Mean of 6 replications, 6 plants each \pm standard deviation.

${ }^{\mathrm{b}}$ Plant height was measured from base of the crown to tip of the apical bud in centimeters $(\mathrm{cm})$

${ }^{\mathrm{c}}$ Mean chlorophyll content of mature leaves measured using a hand-held SPAD meter.

${ }^{\mathrm{d}}$ Significance for linear (L) and quadratic (Q) orthogonal contrasts for Si level.

NS, ${ }^{*}{ }^{* *},{ }^{* * *}$ Nonsignificant or significant at $P \leq 0.10, P \leq 0.01, P \leq 0.001$, respectively.

quadratically increased, then decreased $(P=0.0078)$ in response to increasing Si treatments. The lower Si treatments $\left(50,100\right.$ and $\left.150 \mathrm{mg} \cdot \mathrm{L}^{-1}\right)$ increased the number of leaves compared to the $0 \mathrm{mg} \cdot \mathrm{L}^{-1} \mathrm{Si}$ control treatment, while plants that received the highest Si treatment level had fewer leaves than the control (Table 4). The number of leaves per plant in 'Montego Purple' snapdragon displayed a highly significant linear increase $(P<0.0001)$ as Si concentrations changed from $50 \mathrm{mg} \cdot \mathrm{L}^{-1}$ Si to $200 \mathrm{mg} \cdot \mathrm{L}^{-1} \mathrm{Si}$. The control group had an average mean of 58.07 leaves per plant compared to 72.06 leaves per plant for the highest treatment group $\left(200 \mathrm{mg} \cdot \mathrm{L}^{-1}\right)$. Previous research is lacking on the effect of $\mathrm{Si}$ on the number of leaves per plant, but studies have been conducted to determine the effect of $\mathrm{Si}$ on the leaf area of several crop plant species and number of lateral shoots in bedding plants. Cowpea (Vigna unguiculata) leaf area responded positively to $\mathrm{Si}$ supplementation $\left(100 \mathrm{mg} \mathrm{Si} \mathrm{kg}^{-1}\right)$ by media incorporation of sodium metasilicate $\left(\mathrm{Na}_{2} \mathrm{SiO}_{3} \cdot 9 \mathrm{H}_{2} \mathrm{O}\right)$ [16]. In a study on the effect of Si nutrient solution on the growth of two cultivars of marigolds (Tagetes patula), researchers found the number of lateral shoots significantly increased, as compared to the control [17]. Our results for the number of leaves per plant and reported literature for leaf area indicate that $\mathrm{Si}$ can effect leaf production in plants.

\section{Chlorophyll SPAD Content}

Chlorophyll SPAD content in the leaves of annual bedding plants was found to be significantly affected by Si supplementation. Highly significant correlations are reported between SPAD measurements and the chlorophyll content of leaves in 'Ringo Deep Scarlet' geranium [18] and 'Trailing White' calibrachoa [19]. The chlorophyll SPAD levels in 'Elite Cherry' geranium $(P<0.0001)$, 'Accent White' impatiens $(P=0.0019)$, and 'Delta Premium Marina' pansy $(P=0.0004)$ all responded to $\mathrm{Si}$ treatment concentrations. There was no significant effect on 'Celebrity White' petunia $(P=0.2001)$ and 'Montego Purple' snapdragon $(P=0.6151)$ chlorophyll SPAD content. Silicon supplementation appeared to have an inhibiting effect on 'Elite Cherry' geranium and 'Delta Premium Marina' pansy chlorophyll SPAD content; significant linear decreases were recorded for both species $(P=0.0058$ and $P=0.0011$, respectively; Tables $\mathbf{1}$ and 4). 'Accent White' impatiens had a significant quadratic decrease, then increase $(P=0.0106)$ for chlorophyll SPAD levels as Si treatment increased. The average chlorophyll levels were $36.8 \mathrm{mg} \cdot \mathrm{m}^{-2}$ for control treatment plants, and values increased to 37.5 with $150 \mathrm{mg} \cdot \mathrm{L}^{-1} \mathrm{Si}$ and 38.3 with 200 $\mathrm{mg} \cdot \mathrm{L}^{-1}$ (Table 2). In a study of Si supplementation in cucumbers (Cucumis sativus) cultured in hydroponic nutrient solutions, plants that received $100 \mathrm{mg} \cdot \mathrm{L}^{-1} \mathrm{SiO}_{2}$ in the nutrient solutions exhibited $50 \%$ higher chlorophyll levels than plants that received no Si supplementation [20]. Cucumber plants that received a lower concentration of $\mathrm{Si}\left(10 \mathrm{mg} \cdot \mathrm{L}^{-1} \mathrm{SiO}_{2}\right)$ did not have increased chlorophyll levels [19]. Wang and Galletta [21] found increased chlorophyll content in strawberry (Fragaria ananassa) using the spectrophotometric method of analysis when foliar treatments of $0,4.25,8.50$, 12.75 , or $17.00 \mathrm{mM} \mathrm{Si}$ as $\mathrm{KSiO}_{3}$ were applied. Reported literature and our results with annual bedding plants signify that $\mathrm{Si}$ supplementation influences chlorophyll SPAD content with different application forms and concentrations.

\section{Days to Flower}

Silicon supplementation had little effect on the number of days to flower for the five annual bedding plant species examined. The data recorded for 'Accent White' impatiens $(P=0.001)$ and 'Elite Cherry' geranium $(P<0.0001)$ days to flower was significant in response to $\mathrm{Si}$ treatment levels. The recorded days to flower for 'Accent White' impatiens decreased linearly $(P=0.0049)$ in response to increasing $\mathrm{Si}$ treatments. The reported range for impatiens days to flower in a $20^{\circ} \mathrm{C}$ greenhouse is 84 days [3]. Our control impatiens plants flowered in 81 days with greenhouse temperatures set at $22^{\circ} \mathrm{C}$ day $/ 14^{\circ} \mathrm{C}$ night. 'Accent White' impatiens that re- 
ceived Si treatments had increased days to flower over the control group (Table 2). Days to flower in 'Elite Cherry' geranium decreased, then increased quadratically $(P<0.0001)$ in response to increasing $\mathrm{Si}$ treatments. The average days to flower for the 'Elite Cherry' geranium plants in the control, $150 \mathrm{mg} \cdot \mathrm{L}^{-1} \mathrm{Si}$, and $200 \mathrm{mg} \cdot \mathrm{L}^{-1} \mathrm{Si}$ treatment groups were all similar at 105 days. The remaining treatment groups (50 $\mathrm{mg} \cdot \mathrm{L}^{-1} \mathrm{Si}$ and $150 \mathrm{mg} \cdot \mathrm{L}^{-1} \mathrm{Si}$ ) exhibited 102 days to flower. Previous research with zinnia found $\mathrm{KSiO}_{3}\left(50 \mathrm{~g} \cdot \mathrm{m}^{-} 3\right)$ substrate drenches to delay flowering by 3-5 days compared to the control [14]. Kamenidou et al. [9] conducted a similar study with ornamental sunflowers and had similar results. Flowering was delayed in all groups that received $\mathrm{KSiO}_{3}$ substrate drenches; days to flower was not effected by other Si treatment application forms, including foliar applications of $\mathrm{NaSiO}_{3}$ [9]. Our results, along with previous literature indicate that Si supplementation can have an effect on days to flower, but it is dependent on the application form and plant species.

\section{Flower Diameter}

Silicon supplementation had a limited effect on the flower diameter of the annual bedding plants in this study. 'Accent White' impatiens $(P=0.0164)$ was the only annual species with a significant effect on flower diameter when receiving Si treatments. The flower diameter for 'Celebrity White' petunia $(P=0.1052)$ and 'Delta Premium Marina' pansy $(P=0.2170)$ were not significantly different in response to Si treatments (Tables 3 and 4). The orthogonal contrast for 'Accent White' impatiens flower diameter was a quadratic increase, then decrease $(P=0.0069)$. The average flower diameter for the control group of 'Accent White' impatiens was $3.9 \mathrm{~mm}$, and flower diameter increased to 4.2 $\mathrm{mm}, 4.2 \mathrm{~mm}$ and $4.0 \mathrm{~mm}$ for the treatments of 50,100 and $150 \mathrm{mg} \cdot \mathrm{L}^{-1} \mathrm{Si}$, respectively. Kamenidou et al. [9] reported the flower diameter of ornamental sunflower increased with Si supplementation by incorporation of rice husk ash (100 $\left.\mathrm{g} \cdot \mathrm{m}^{-3}\right)$, foliar applications of $\mathrm{NaSiO}_{3}\left(100 \mathrm{mg} \cdot \mathrm{L}^{-1}\right)$, and incorporation of hydrous $\mathrm{KSiO}_{3}\left(140 \mathrm{~g} \cdot \mathrm{m}^{-3}\right)$. In the same study they found a decrease in flower diameter with substrate drenches of $\mathrm{KSiO}_{3}\left(200 \mathrm{mg} \cdot \mathrm{L}^{-1}\right)$ [9]. Kamenidou et al. [14] reported zinnia flower diameter increased with $\mathrm{NaSiO}_{3}$ foliar applications (100 and $150 \mathrm{mg} \cdot \mathrm{L}^{-1}$ ), substrate incorporated rice husk ash $\left(100 \mathrm{~g} \cdot \mathrm{m}^{-3}\right)$, substrate incorporated hydrous $\mathrm{KSiO}_{3}\left(140 \mathrm{~g} \cdot \mathrm{m}^{-3}\right)$ and substrate drenches of $\mathrm{KSiO}_{3}(100$ $\mathrm{mg} \cdot \mathrm{L}^{-1}$ ). Dębicz and Wróblewska [22] found foliar applications of Actisil $\left(\mathrm{H}_{4} \mathrm{SiO}_{4}\right)$ to decrease flower diameter of vervain 'Patio Blue' (Verbena sp.), while creeping zinnia 'Sunbini' (Sanvitalia speciosa) and purslane 'Duna Red' (Portulaca umbraticola) had increased flower diameter with $\mathrm{Si}$ supplementation. Along with previous research, our research indicates that the effect of $\mathrm{Si}$ on the flower diameter is species, application form and rate dependent.

\section{Experiment 2: Titanium (Ti) Supplementation}

\section{Plant Height}

Plant heights of 'Elite Cherry' geranium $(P<0.0001)$, 'Celebrity White' petunia $(P=0.0944)$, 'Delta Premium Marina' pansy $(P=0.0326)$ and 'Montego Purple' snapdragon $(P=0.0129)$ were significantly affected by Ti supplementation. Titanium treatments had no significant effect on plant height of 'Accent White' impatiens $(P=0.4295)$. The plant heights of the control treatments of all species were within reported ranges (Tables 6-10) [3]. The plant height of ' $\mathrm{Ce}-$ lebrity White' petunia responded negatively, while 'Montego Purple' snapdragon responded positively to Ti supplementation. 'Celebrity White' petunia had a linear decrease $(P=0.0381)$ while 'Montego Purple' snapdragon had a linear increase $(P=0.0033)$ in response to increasing foliar applied Ti treatments. Plant height increased, then decreased quadratically for 'Elite Cherry' geranium $(P \leq 0.0001)$ to increasing Ti treatments. The plant height for 'Elite Cherry' geranium increased from $7.6 \mathrm{~cm}$ for the control group to $8.6 \mathrm{~cm}$ for both the 50 and $75 \mathrm{mg} \cdot \mathrm{L}^{-1} \mathrm{Ti}$ treatment groups (Table 6). Based on a review of literature, this is the first report of $\mathrm{Ti}$ supplementation on annual bedding plants. Previous research by Wojcik and Wojcik [23] found that Ti foliar sprays increased biomass of the apple (Malus domestica) variety 'Emla', which likely resulted from the stimulation of phosphorus (P) and zinc (Zn) uptake by Ti. Phosphorus and $\mathrm{Zn}$ stimulate cell division and regulate plant growth [24]. Plant tissue elements were not measured in this study, therefore we cannot conclude that responses in plant height from Ti applications were due, in part, to increases in the uptake of other elements.

Previous research suggests that Ti supplementation can affect plant height and this effect is species specific in annual bedding plants.

\section{Stem Diameter}

Increasing foliar $\mathrm{Ti}$ treatments affected the stem diameter in 'Accent White' impatiens $(P=0.0036)$ and 'Montego Purple' snapdragon $(P=0.0306)$. The stem diameter of 'Accent White' impatiens exhibited a linear decrease $(P=0.0214)$ as $\mathrm{Ti}$ treatments increased. The stem diameter for 'Accent White' impatiens decreased from $8.9 \mathrm{~mm}$ for the control group to $7.4 \mathrm{~mm}$ for the $100 \mathrm{mg} \cdot \mathrm{L}^{-1} \mathrm{Ti}$ treatment group (Table 10). Former studies with Ti foliar supplementation to apple 'Emla' found an increased biomass of the apple [23].

\section{Number of Leaves}

The number of leaves per plant of the annual bedding plant species was significantly affected by Ti supplementation. The number of leaves per plant of 'Elite Cherry' geranium $(P<0.0001)$, 'Accent White' impatiens $(P=0.0178)$, 'Celebrity White' petunia $(P=0.0583)$, 'Delta Premium Marina' pansy $(P=0.006)$, and 'Montego Purple' snapdragon $(P<0.0001)$ varied in response to Ti supplementation. Titanium supplementation had an inhibiting effect on the number of leaves per plant, producing a linear decrease in 'Accent White' impatiens $(P=0.0016)$ and 'Celebrity White' petunia $(P=0.0176)$. The number of leaves per plant in 'Elite Cherry' geranium exhibited a quadratic increase, then decrease $(P \leq 0.0001)$ as $\mathrm{Ti}$ treatments increased (Table 6). 'Montego Purple' snapdragon leaf number per plant displayed a highly significant linear increase $(P<0.0001)$ as $\mathrm{Ti}$ concentrations increased. The control snapdragon group had an average mean of 58.07 leaves per plant compared to 74.27 leaves per plant for the highest treatment group $\left(100 \mathrm{mg} \cdot \mathrm{L}^{-1}\right)$ (Table 9). Kopsell et al. [25] studied the effect of Ti foliar applications on spinach (Spinacia oleracea) and found it to have no effect on the leafy biomass, but it did increase concentrations of 
Table 6. Mean values ${ }^{\mathrm{a}}$ of 'Elite Cherry' geranium growth parameters after plants reached marketable size under greenhouse conditions at Illinois State University, Normal, IL with titanium treatments (Ti LEVEL) varying from $0 \mathrm{mg}^{\mathrm{Ti}} \cdot \mathrm{L}^{-1}$ to $100 \mathrm{mg}$ $\mathbf{T i} \cdot \mathbf{L}^{-1}$.

\begin{tabular}{|c|c|c|c|c|}
\hline $\begin{array}{c}\text { Ti LEVEL } \\
\left(\mathrm{mg} \cdot \mathrm{L}^{-1}\right)\end{array}$ & $\begin{array}{c}\text { Plant Height }^{\mathrm{b}} \\
(\mathrm{cm})\end{array}$ & $\begin{array}{l}\text { Days to Flower } \\
\quad \text { (anthesis) }\end{array}$ & $\begin{array}{c}\text { SPAD } \\
\text { Chlorophyll }^{\mathrm{c}} \\
\left(\mathrm{mg} \cdot \mathrm{m}^{-2}\right)\end{array}$ & Number of Leaves \\
\hline 25 & $7.6 \pm 1.26$ & $100.67 \pm 0.48$ & $49.9 \pm 3.03$ & $17.58 \pm 2.92$ \\
\hline 50 & $8.6 \pm 1.37$ & $100.00 \pm 1.91$ & $53.4 \pm 1.85$ & $18.42 \pm 2.43$ \\
\hline 100 & $7.0 \pm 1.05$ & $105.33 \pm 2.73$ & $52.8 \pm 2.64$ & $16.22 \pm 1.66$ \\
\hline \multicolumn{5}{|l|}{ Contrast $^{\mathrm{d}}$} \\
\hline $\mathrm{L}$ & NS & NS & $* *$ & NS \\
\hline
\end{tabular}

${ }^{\text {a }}$ Mean of 6 replications, 6 plants each \pm standard deviation.

${ }^{\mathrm{b}}$ Plant height was measured from base of the crown to tip of the apical bud in centimeters $(\mathrm{cm})$

${ }^{\mathrm{c}}$ Mean chlorophyll content of mature leaves measured using a hand-held SPAD meter.

${ }^{\mathrm{d}}$ Significance for linear (L) and quadratic (Q) orthogonal contrasts for Ti level.

NS, ${ }^{* *},{ }^{* * *}$ Nonsignificant or significant at $P \leq 0.01, P \leq 0.001$, respectively.

Table 7. Mean values ${ }^{\mathrm{a}}$ of 'Celebrity White' petunia growth parameters after plants reached marketable size under greenhouse conditions at Illinois State University, Normal, IL with titanium treatments (Ti LEVEL) varying from $0 \mathrm{mg}^{\mathrm{T} i} \cdot \mathrm{L}^{-1}$ to 100 $\operatorname{mg~Ti} \cdot \mathbf{L}^{-1}$.

\begin{tabular}{|c|c|c|c|c|c|}
\hline $\begin{array}{l}\text { Ti LEVEL } \\
\left(\mathrm{mg} \cdot \mathrm{L}^{-1}\right)\end{array}$ & $\begin{array}{c}\text { Plant Height }{ }^{\mathrm{b}} \\
(\mathrm{cm})\end{array}$ & $\begin{array}{l}\text { Days to Flower } \\
\quad \text { (anthesis) }\end{array}$ & $\begin{array}{c}\text { SPAD } \\
\text { Chlorophyll }^{\mathrm{c}} \\
\left(\mathrm{mg} \cdot \mathrm{m}^{-2}\right)\end{array}$ & Number of Leaves & $\begin{array}{l}\text { Flower Diameter } \\
\qquad(\mathrm{mm})\end{array}$ \\
\hline 25 & $10.4 \pm 0.63$ & $78.41 \pm 1.97$ & $34.8 \pm 1.73$ & $27.42 \pm 2.75$ & $5.9 \pm 0.26$ \\
\hline 50 & $11.1 \pm 1.74$ & $76.16 \pm 2.23$ & $32.9 \pm 2.58$ & $26.40 \pm 1.52$ & $5.8 \pm 0.19$ \\
\hline 100 & $10.3 \pm 0.60$ & $75.97 \pm 1.07$ & $36.6 \pm 2.77$ & $26.35 \pm 2.91$ & $5.7 \pm 0.52$ \\
\hline \multicolumn{6}{|l|}{ Contrast $^{\mathrm{d}}$} \\
\hline $\mathrm{L}$ & $*$ & $*$ & NS & $*$ & $*$ \\
\hline
\end{tabular}

${ }^{\text {a }}$ Mean of 6 replications, 6 plants each \pm standard deviation.

${ }^{\mathrm{b}}$ Plant height was measured from base of the crown to tip of the apical bud in centimeters $(\mathrm{cm})$.

${ }^{\mathrm{c}}$ Mean chlorophyll content of mature leaves measured using a hand-held SPAD meter.

${ }^{\mathrm{d}}$ Significance for linear (L) and quadratic (Q) orthogonal contrasts for Ti level.

NS, ${ }^{*},{ }^{* * *}$ Nonsignificant or significant at $P \leq 0.10, P \leq 0.001$, respectively.

$\mathrm{Ti}, \mathrm{Mg}$ and $\mathrm{Ca}$ in shoot tissue. Previous research, along with our study, supports that Ti supplementation can affect the number of leaves per plant.

\section{Chlorophyll SPAD Content}

Titanium supplementation significantly affected the chlorophyll SPAD content in the leaves of annual bedding plants. The chlorophyll SPAD content in 'Elite Cherry' geranium $(P<0.0001)$, 'Accent White' impatiens $(P=0.0006)$, 'Celebrity White' petunia $(P=0.0005)$ and 'Delta Premium Marina' pansy $(P=0.0006)$ varied in response to Ti treatments. 'Mon- tego Purple' snapdragon ( $P=0.8082)$ chlorophyll SPAD content was not significant. Titanium supplementation linearly decreased the chlorophyll SPAD measurement of 'Accent White' impatiens ( $P=0.0165)$. Chlorophyll SPAD of 'Celebrity White' petunia decreased, then increased quadratically $(P=0.0001)$. The control group for 'Celebrity White' petunia had higher chlorophyll SPAD content than all Ti treatment groups (Table 7). 'Elite Cherry' geranium chlorophyll SPAD content exhibited a linear increase $(P=0.0024)$ as Ti treatments increased (Table 6). Previous research in apple, plum (Prunus salicina), oats (Aena sativa 'Zlatak') and spinach 
Table 8. Mean values ${ }^{a}$ of 'Delta Premium Marina' pansy growth parameters after plants reached marketable size under greenhouse conditions at Illinois State University, Normal, IL with titanium treatments (Ti LEVEL) varying from 0 mg Ti $\cdot \mathrm{L}^{-1}$ to $100 \mathrm{mg} \mathrm{Ti} \cdot \mathbf{L}^{-1}$.

\begin{tabular}{|c|c|c|c|c|c|}
\hline $\begin{array}{c}\text { Ti LEVEL } \\
\left(\mathrm{mg} \cdot \mathrm{L}^{-1}\right)\end{array}$ & $\begin{array}{l}\text { Plant Height }^{\mathrm{b}} \\
\text { (cm) }\end{array}$ & $\begin{array}{l}\text { Days to Flower } \\
\quad \text { (anthesis) }\end{array}$ & $\begin{array}{c}\text { SPAD } \\
\text { Chlorophyll }^{\mathrm{c}} \\
\left(\mathrm{mg} \cdot \mathrm{m}^{-2}\right)\end{array}$ & Number of Leaves & $\begin{array}{c}\text { Flower Diameter } \\
(\mathrm{mm})\end{array}$ \\
\hline 25 & $3.2 \pm 0.41$ & $79.85 \pm 1.18$ & $48.9 \pm 2.81$ & $22.69 \pm 2.72$ & $5.1 \pm 0.16$ \\
\hline 50 & $2.9 \pm 0.45$ & $82.75 \pm 2.66$ & $53.1 \pm 1.88$ & $19.42 \pm 2.27$ & $5.7 \pm 0.38$ \\
\hline 100 & $2.9 \pm 0.33$ & $80.56 \pm 1.48$ & $46.6 \pm 3.13$ & $21.17 \pm 2.17$ & $5.1 \pm 0.32$ \\
\hline \multicolumn{6}{|l|}{ Contrast $^{\mathrm{d}}$} \\
\hline $\mathrm{L}$ & NS & NS & NS & NS & NS \\
\hline
\end{tabular}

${ }^{\text {a }}$ Mean of 6 replications, 6 plants each \pm standard deviation.

${ }^{\mathrm{b}}$ Plant height was measured from base of the crown to tip of the apical bud in centimeters $(\mathrm{cm})$.

${ }^{c}$ Mean chlorophyll content of mature leaves measured using a hand-held SPAD meter.

${ }^{\mathrm{d}}$ Significance for linear (L) and quadratic (Q) orthogonal contrasts for Ti level.

${ }^{\mathrm{NS}}$ Nonsignificant.

Table 9. Mean values 'a 'Montego Purple' snapdragon' growth parameters after plants reached marketable size under greenhouse conditions at Illinois State University, Normal, IL with titanium treatments (Ti LEVEL) varying from $0 \mathrm{mg}^{\mathrm{Ti}} \cdot \mathrm{L}^{-1}$ to $100 \mathrm{mg} \mathrm{Ti} \cdot \mathrm{L}^{-1}$.

\begin{tabular}{|c|c|c|c|c|c|}
\hline $\begin{array}{c}\text { Ti LEVEL } \\
\left(\mathrm{mg} \cdot \mathrm{L}^{-1}\right)\end{array}$ & $\begin{array}{c}\text { Plant Height }^{\mathrm{b}} \\
(\mathrm{cm})\end{array}$ & $\begin{array}{l}\text { Days to Flower } \\
\text { (anthesis) }\end{array}$ & $\begin{array}{c}\text { SPAD } \\
\text { Chlorophyll }^{\mathrm{c}} \\
\left(\mathrm{mg} \cdot \mathrm{m}^{-2}\right)\end{array}$ & Number of Leaves & $\begin{array}{c}\text { Stem Diameter } \\
(\mathrm{mm})\end{array}$ \\
\hline 25 & $12.0 \pm 0.89$ & $60.50 \pm 0.0$ & $44.2 \pm 1.70$ & $69.31 \pm 0.24$ & $2.3 \pm 0.11$ \\
\hline 50 & $12.7 \pm 0.78$ & $60.50 \pm 0.0$ & $45.0 \pm 2.40$ & $67.15 \pm 1.44$ & $2.5 \pm 0.32$ \\
\hline 100 & $12.5 \pm 1.01$ & $60.60 \pm 0.0$ & $44.2 \pm 3.05$ & $74.27 \pm 0.66$ & $2.4 \pm 0.19$ \\
\hline \multicolumn{6}{|l|}{ Contrast $^{\mathrm{d}}$} \\
\hline $\mathrm{L}$ & $* *$ & NS & NS & $* * *$ & NS \\
\hline
\end{tabular}

${ }^{a}$ Mean of 6 replications, 6 plants each \pm standard deviation.

${ }^{\mathrm{b}}$ Plant height was measured from base of the crown to tip of the apical bud in centimeters $(\mathrm{cm})$

${ }^{\mathrm{c}}$ Mean chlorophyll content of mature leaves measured using a hand-held SPAD meter.

${ }^{\mathrm{d}}$ Significance for linear (L) and quadratic (Q) orthogonal contrasts for Ti level.

NS, ${ }^{* *},{ }^{* * *}$ Nonsignificant or significant at $P \leq 0.01, P \leq 0.001$, respectively.

found Ti supplementation to increase concentrations of magnesium $(\mathrm{Mg})$, copper $(\mathrm{Cu})$, and iron $(\mathrm{Fe})$ [23, 25-27]. Magnesium, $\mathrm{Cu}$ and $\mathrm{Fe}$ are all essential in the creation of chlorophyll through photosynthesis in the plants [24]. Our study, along with previous research suggests that $\mathrm{Ti}$ supplementation can affect the chlorophyll SPAD measurement in annual bedding plant species.

\section{Days to Flower}

Foliar Ti supplementation had a significant effect on the days to flower for 'Elite Cherry' geranium $(P<0.0001)$, and
'Celebrity White' petunia ( $P=0.0713)$. Titanium treatments had no effect on days to flower for 'Accent White' impatiens $(P=0.2216)$, 'Delta Premium Marina' pansy $(P=0.078)$, and 'Montego Purple' snapdragon $(\mathrm{P}>0.10)$, which days to flower were virtually identical for all treatment groups. The days to flower for the control treatments of all species were within reported ranges (Tables 6-7) [3]. 'Elite Cherry' geranium days to flower exhibited a quadratic decrease, then increase $(P<0.0001)$ as Ti treatments increased. The number of days to flower for the control group of 'Elite Cherry' geranium was 105; it decreased to 100 days for three of the 
Table 10. Mean values ${ }^{a}$ of 'Accent White' impatiens growth parameters after plants reached marketable size under greenhouse conditions at Illinois State University, Normal, IL with titanium treatments (Ti LEVEL) varying from $0 \mathrm{mg}^{\mathrm{T} i} \cdot \mathrm{L}^{-1}$ to 100 $\mathbf{m g ~ T i} \cdot \mathbf{L}^{-1}$.

\begin{tabular}{|c|c|c|c|c|c|c|}
\hline $\begin{array}{c}\text { Ti LEVEL } \\
\left(\mathrm{mg} \cdot \mathrm{L}^{-1}\right)\end{array}$ & $\begin{array}{c}\text { Plant Height }^{\mathrm{b}} \\
(\mathrm{cm})\end{array}$ & $\begin{array}{l}\text { Days to Flower } \\
\text { (anthesis) }\end{array}$ & $\begin{array}{c}\text { SPAD } \\
\text { Chlorophyll }^{\mathrm{c}} \\
\left(\mathrm{mg} \cdot \mathrm{m}^{-2}\right)\end{array}$ & $\begin{array}{l}\text { Number of } \\
\text { Leaves }\end{array}$ & $\begin{array}{l}\text { Stem Diameter } \\
(\mathbf{m m})\end{array}$ & $\begin{array}{l}\text { Flower Diameter } \\
\text { (cm) }\end{array}$ \\
\hline 25 & $7.7 \pm 1.08$ & $82.50 \pm 1.74$ & $35.4 \pm 2.59$ & $29.14 \pm 1.48$ & $7.7 \pm 0.57$ & $4.2 \pm 0.14$ \\
\hline 50 & $8.3 \pm 1.02$ & $82.87 \pm 1.36$ & $39.9 \pm 1.46$ & $29.36 \pm 1.72$ & $8.2 \pm 0.80$ & $4.1 \pm 0.20$ \\
\hline 100 & $7.4 \pm 0.42$ & $83.75 \pm 2.37$ & $33.2 \pm 2.62$ & $27.17 \pm 1.76$ & $7.4 \pm 0.28$ & $3.9 \pm 0.21$ \\
\hline \multicolumn{7}{|l|}{ Contrast $^{\mathrm{d}}$} \\
\hline $\mathrm{L}$ & NS & $*$ & $*$ & $* *$ & $*$ & NS \\
\hline Q & NS & $*$ & $*$ & $* *$ & * & * \\
\hline
\end{tabular}

${ }^{a}$ Mean of 6 replications, 6 plants each \pm standard deviation.

${ }^{b}$ Plant height was measured from base of the crown to tip of the apical bud in centimeters $(\mathrm{cm})$

${ }^{\mathrm{c}}$ Mean chlorophyll content of mature leaves measured using a hand-held SPAD meter.

${ }^{\mathrm{d}}$ Significance for linear (L) and quadratic (Q) orthogonal contrasts for Ti level.

NS, *, ${ }^{* *}$ Nonsignificant or significant at $P \leq 0.10, P \leq 0.01$, respectively.

treatment groups, 25,50 and $100 \mathrm{mg} \cdot \mathrm{L}^{-1}$ (Table 6). The days to flower for 'Celebrity White' petunia decreased linearly $(P=0.0109)$ in response to increasing Ti concentration. When compared to the control group, the days to flower decreased one day when supplied with $50 \mathrm{mg} \cdot \mathrm{L}^{-1}$ and two days with 75 and $100 \mathrm{mg} \cdot \mathrm{L}^{-1}$ treatment groups.

\section{Flower Diameter}

Titanium supplementation had little effect on the flower diameter of annual bedding plants. The flower diameter was not significant for 'Accent White' impatiens $(P=0.0711)$ and 'Celebrity White' petunia $(P=0.2734)$. Data recorded for 'Delta Premium Marina' pansy flower diameter exhibited significance in the model; however, the regression was not significant (Table 8). In the annual bedding plant species tested Ti supplementation did not have an effect on flower diameter.

\section{CONCLUSION}

Silicon and Ti foliar supplementation influenced growth and quality characteristics of selected annual bedding plants. However, effects varied among species and foliar nutrient concentrations. Therefore, at the present time it is difficult to recommend a single treatment concentration of each for annual bedding plant growth and quality enhancement. Further research is needed to assess specific impacts of $\mathrm{Si}$ and $\mathrm{Ti}$ on additional annual crop species and varieties grown in soilless media. The exact mode of action of the effect of Si and Ti on annual bedding plant morphology also needs to be determined. Once the degree of effectiveness of Si and Ti to all annual bedding plants is concluded, an economic analysis would be useful to assess if supplemental $\mathrm{Si}$ and $\mathrm{Ti}$ are cost effective and affordable for greenhouse growers.

\section{CONFLICT OF INTEREST}

The authors confirm that this article content has no conflicts of interest.

\section{ACKNOWLEDGEMENTS}

This research was funded by University Research Grant (URG) from the College of Applied Sciences and Technology (CAST) at Illinois State University. It partially fulfilled the requirement for an M.S. degree for BrittnayWhittedHagg, completed in May 2012. The authors would like to thank Jeremy Haag, Carly Divito and Adria Thomas for their assistance in plant culture and data collection.

\section{REFERENCES}

[1] United States Department of Agriculture. Floriculture Report, 2010 Summary. Washington: NASS 2011.

[2] Anderson B. Bedding Plants. Univ Kent Coop Ext Fact Sheet 2002; Revised May 2010.

[3] Hamrick D, Ed. Ball Redbook- Crop Production. Ball Publishing, 335 N River St., PO Box 9, Batavia, IL 60510, 2003.

[4] Reed DW, Ed. A Grower's guide to water, media and nutrition for greenhouse crops. Ball Publishing, 335 N River St., PO Box 9, Batavia, IL 60510, 1996.

[5] Mills HA, Jones Jr JB. Plant Analysis Handbook II: a practical sampling, preparation, analysis, and interpretation Guide. MicroMacro Publishing: Athens, GA 1996.

[6] Snyder GH, Matichenkov VV, Datnoff LE. In: Barker AV, Pilbeam DJ, Eds. Silicon. Handbook of Plant Nutrition, CRC Press: Boca Raton FL 2007; pp. 551-62.

[7] Emsley J. Nature's building blocks: An A to Z guide to the elements. Oxford University Press: New York 2001.

[8] Prasad S, Kumar K. Greenhouse management for horticultural crop production. Agrobios: Jodhpur, India 1999.

[9] Kamenidou S, Cavins T, Marek S. Silicon supplement affect horticultural traits of greenhouse-produced ornamental sunflowers. Hortic Sci 2008; 43: 236-9.

[10] Ranger CM, Singh AP, Frantz JM, et al. Influence of silicon on resistance of Zinnia elegans to Myzuspersicae. Environ Entomol 2009; 38: 129-36.

[11] Savvas D, Giotis D, Chatzieustratiou E, Bakea M, Patakioutas G. Silicon supply in soilless cultivations of zucchini alleviates stress induced by salinity and powdery mildew infections. Environ Exp Bot 2009; 65:11-7.

[12] Carvajal M, Alcaraz CF. Why titanium is a beneficial element for plants. J Plant Nutr 1998; 21: 655-64. 
[13] Kuzel S, Hruby M, Cigler P, Tlustos P, Van PN. Mechanism of physiological effects of titanium leaf sprays on plants grown on soil. Biol Trace Elem Res 2003; 91:179-89.

[14] Kamenidou S, Cavins T, Marek S. Evaluation of silicon as a nutritional supplement for greenhouse zinnia production. Sci Hortic 2009; 119: 297-301.

[15] Kamenidou S, Cavins T, Marek S. Correlation between tissue and substrate silicon concentrations of greenhouse produced ornamental sunflowers. J Plant Nutr 2011; 34: 217-23.

[16] Mali M, Aery NC. Effect of silicon on growth, biochemical constituents and mineral nutrition of cowpea. Com Soil Sci Plant Anal 2009; 40: 1041-52.

[17] Sivanesan I, Son MS, Lee JP, Jeong BR. Effects of silicon on growth of Tagetespatula L. 'Boy Orange' and 'Yellow Boy' seedlings cultured in an environment controlled chamber. Prop Orn Plants 2010; 10(3): 136-40.

[18] Smith BR, Fisher PR, Argo WR. Water-soluble fertilizer concentrations and $\mathrm{pH}$ of a peat-based medium affect growth, nutrient uptake, and chlorosis of container-grown seed geraniums (Pelargonium $x$ hortorum L.H. Bail). J Plant Nutr 2004; 27(3): 497-524.

[19] Wik RM, Fisher PR, Kopsell DA. Iron form and concentration affect nutrition of container-grown Pelargonium and Calibrachoa. Hortic Sci 2006; 41(1): 244-51.
[20] Adatia MH, Besford RT. The effects of silicon on cucumber plants grown in recirculating nutrient solutions. Annal Bot 1986; 58(3): 343-31.

[21] Wang SY, Galletta GJ. Foliar application and potassium silicate induces metabolic changes in strawberry plants. J Plant Nutr 1998; 21(1): 157-67.

[22] Dębicz R, Wróblewska K. The effect of silicon foliar application on the development of seasonal ornamental plants. PART I: Sanvitalia speciosa 'Sunbini', Verbena 'Patio Blue' and Portulaca umbraticola 'Duna Red'. Acta Agrobot 2011; 64(4): 99-106.

[23] Wojcik P, Wojcik M. Growth and nutrition of M.26 EMLA apple rootstock as influenced by titanium fertilization. J Plant Nutr 2001; 24: $1575-88$.

[24] Ingels JE. Ornamental Horticulture: Science, Operations and Management. Delmar: New York 2010.

[25] Kopsell D, McElroy S, Sams C. Spinach shoot tissue nutrient concentrations respond to foliar applications of chelated titanium. Hortic Sci 2007; 42: 924 (Abstr.).

[26] Hruby M, Cigler P, Kuzel S. Contribution to understanding the mechanism of titanium action in plants. J Plant Nutr 2002; 25: 577 98.

[27] Alcaraz-Lopez C, Botia M, Alcaraz CF, RiquelmeF. Effects of calcium-containing foliar sprays combined with titanium and algae extract on plum fruit quality. J Plant Nutr 2004; 27(4): 713-29.

(C) Whitted-Haag et al.; Licensee Bentham Open.

This is an open access article licensed under the terms of the Creative Commons Attribution Non-Commercial License (http://creativecommons.org/licenses/by-nc/3.0/) which permits unrestricted, non-commercial use, distribution and reproduction in any medium, provided the work is properly cited. 